\author{
Agnieszka Kotlińska-Toma \\ Uniwersytet Wrocławski \\ agnieszka.kotlinska-toma@uwr.edu.pl
}

\title{
Kto się boi Alkestis, czyli Eurypidesa „kobieta bez złudzeń”
}

\begin{abstract}
Who's Afraid of Alcestis, or Euripides' "Woman of No Illusions"

The aim of this paper is to present ancient and modern interpretations of the character of Alcestis in Euripides' play. The analysis focuses on the understanding of family duties and the consequences of respecting or violating philia in the Greek oikos. A detailed examination of the demeanour of both Admetus and Alcestis shows how the family relationships are being gradually and irremediably destroyed. The Euripidean version of the myth ends, in my opinion, in the tragic collapse of the House of Admetus, and the presumed laetus exitus is a way of avoiding the final presentation of the real (and obvious for the audience) repercussions of Alcestis's death and return.
\end{abstract}

Key words: Alcestis, Eurypides, Greek tragedy 
Clarissimae Doctrici Danutae Łowicka septuagesimum quintum diem natalem celebranti.

Często cię Muz służebnicy

Będą śpiewać - przy dźwięku strun siedmiu

Na skorupie żółwiowej rozpiętych

Lub też w pieśniach bez liry cię sławiąc

(...)

Taką w śmierci twej zostawiłaś

Pieśń-opowieść dla śpiewów pieśniarzy ${ }^{1}$.

Powyższe słowa to początek antystrofy drugiego stasimonu Alkestis Eurypidesa (w. 445-454), poetyckie proroctwo, którego wypełnienia świadkami będzie kolejne dwadzieścia pięć wieków ludzkości. Niewiele tematów tragicznych doczekało się bowiem takiej popularności wśród potomnych jak właśnie sztuka dotycząca kobiety umierającej, by ocalić życie męża. Historia o Admecie i jego pełnej poświęcenia żonie znana była wśród Greków w różnych wersjach, czego dowodem jest choćby zachowany tekst tzw. Admetou Logos ${ }^{2}$. Ten mit, czerpiący wiele $\mathrm{z}$ folkloru i baśniowych opowieści, stał się kanwą dramatu na długo przed Eurypidesem - pierwszy wprowadził go na scenę Frynich ${ }^{3}$. Nie wiemy, jaka była fabuła tej sztuki. Z pewnością, choćby z powodów czysto technicznych związanych z możliwościami i estetyką adaptacji dramatycznej, znacząco różniła się

1 Jeśli nie zaznaczono inaczej, wszystkie tłumaczenia tekstu Eurypidesa za: Eurypides, Tragedie, przeł. i oprac. J. Łanowski, Warszawa 1967.

2 Skolion przypisywany poetce Praksilli ( 3 = Carm. Conv. 14 PMG), omówie-

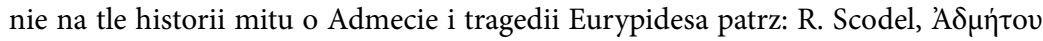

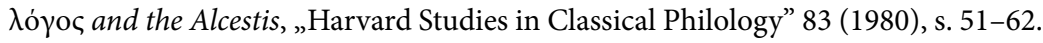

3 Sztuka znana jest tylko z tytułu, który cytuje księga Suda ( $\varphi 762)$, nieznany i dyskutowany jest gatunek dramatyczny, w którym opowiedział mit Frynich. Co ciekawe tragediopisarz ten znany jest właśnie $\mathrm{z}$ wprowadzenia kobiet jako postaci dramatu (granych na scenie oczywiście przez mężczyzn), z zachowanych dziewięciu tytułów dwa: Danaidy i Kobiety z Pleuron odnoszą się do kobiecego chóru, a jeden, właśnie Alkestis, wskazuje na kobiecą rolę tytułową. 
od przedstawienia Eurypidesa ${ }^{4}$. Podkreślić należy, że we wszystkich znanych nam antycznych wersjach to król jest postacią centralną. Jest tak również w sztuce Eurypidesa, której premiera ${ }^{5}$ odbyła podczas Wielkich Dionizjów w miesiącu elafebolion roku 438 za archontatu Glaukinosa. Wydaje się, że podobnie jak inne dzieła wybitnego tragika, także i Alkestis przypadła do gustu publiczności dopiero w epokach późniejszych. Psychologizujące i realistyczne przedstawienie postaci oraz poruszanie zagadnień natury ludzkiej zyskało szczególną popularność w czasach hellenistycznych, gdy w filozofii, literaturze, a także estetyce i samej koncepcji dzieł artystycznych zauważamy wyraźne przeniesienie akcentu na problemy jednostki i odejście od rozumienia świata wyłącznie w perspektywie wspólnoty ${ }^{6}$. Od tej pory dzieło Eurypidesa staje się punktem odniesienia nie tylko dla poetów, dramaturgów, ale także rzeźbiarzy ${ }^{7}$ Paradygmatyczna postać oddanej żony zyskała wyjątkową aprobatę u Rzymian, może ze

4 Z oczywistych względów dyktowanych objętością artykułu zmuszona jestem zrezygnować z omówienia dyskusji dotyczącej gatunków obu dramatów, szczególnie prosatyrowego i tragikomicznego charakteru Alkestis Eurypidesa, a także z odniesienia się do wszystkich interesujących w tej sztuce zagadnień.

${ }^{5}$ Różne świadectwa, między innymi papirus $P$. Oxy. 4546, dowodzą, że Alkestis Eurypidesa była wystawiana w kolejnych wiekach, a zatem termin „premiera” jest tutaj w pełni uzasadniony.

6 O popularności Eurypidesa w epokach późniejszych patrz: S. Nervegna, Staging Scenes or Plays? Theatrical Revivals of „Old” Greek Drama in Antiquity, "Zeitschrift für Papyrologie und Epigraphik” 162 (2007), s. 14-42, eadem, Performing Classics. The Tragic Canon in the Fourth Century and Beyond, w: Greek Theatre in the Fourth Century BC, ed. by E. Csapo, H.R. Goette, J.R. Green, P. Wilson, Göttingen 2014, s. 157-188, oraz M. Revermann, The Reception of Greek Tragedy from 500-323 BC, w: A Handbook to the Reception of Greek Drama, ed. by B. van Zyl Smit, Chichester 2016, s. 11-28, i S. Miles, Greek Drama in the Hellenistic World, w: A Handbook to the Reception of Greek Drama..., s. 45-62.

7 Szczególnie popularne staje się przedstawianie sceny powrotu Alkestis na sarkofagach w epoce imperialnej, motyw ten pojawia się nawet w zabytkach chrześcijańskich, co tłumaczyć można nie tylko swoistym eklektycznym podejściem do problemu zmartwychwstania, ale także popularnością sztuki, której bohaterem jest cnotliwa żona i pogromca zła (patrz: B. Berg, Alcestis and Hercules in the Catacomb of Via Latina, „Vigiliae Christianae” 49 (1994), s. 219-234 z dalszą bibliografią). 
względu na bliski ich mentalności i tradycji ideał uxor univira. $\mathrm{Na}$ przełomie II i I wieku p.n.e. tragedię zatytułowaną Alkestis napisał Lucjusz Akcjusz. Należy domniemywać, że w dużej mierze i w epoce imperialnej większym zainteresowaniem cieszyły się wady Admeta, niż cnota Alkestis, skoro zarówno Juwenalis (6.652-654), jak i Lukian (Salt. 15-16) poświadczają przedstawienia mimiczne na bazie tego mitu. Do literatury nowożytnej przeniknęła historia oddanej żony dzięki dwóm łacińskim mitografom: Hyginusowi ${ }^{8}$, wyzwoleńcowi cesarza Augusta, i Fulgencjuszowi ${ }^{9}$. Nie wiadomo, czyja literacka wersja mitu posłużyła Fulgencjuszowi za podstawę jego alegorycznej opowieści o Admecie i Alkestis (1.22), istotne różnice w treści legendy wskazują, że nie była to z pewnością tragedia Eurypidesa. Obok wariantu Hyginusa, którego druga część jest streszczeniem wersji Eurypidejskiej, to właśnie tekst Fulgencjusza znany był pierwszym twórcom renesansowym, którzy sięgnęli po antyczny przykład oddanej żony. Wśród nich najważniejszą rolę odegrał oczywiście Giovanni Boccaccio ${ }^{10}$. Stałą w miłości i poświęceniu żonę przedstawił Geoffrey Chaucer w Czytaniu o dobrych paniach, który tym samym wprowadził ją do literatury angielskiej ${ }^{11}$. Podobnie cnotliwą żonę

8 Fabulae 50 i 51.

9 Fabius Planciades Fulgentius - prozaik łaciński żyjący na przełomie V i VI w. n.e. Szczególnie znanym jego dziełem były trzy księgi mitograficzne.

10 W dziele Genealogiae Deorum Gentilium $(13,1)$ ujawnia swoje źródło słowami: „De Alchista ad Admetum ab Inferis revocata dicit Fulgentius, quod...”. Jego alegoryczna interpretacja jest szczególnie godna zapamiętania dla czytelnika niniejszego artykułu, ponieważ znacząco różni się od przesłania Eurypidesa, streszczają je zaś słowa Boccaccia: „Admetus anima rationalis est, cui tunc Alchista, id est virtus”. Cytat za wydaniem: Giovanni Boccaccio, Genealogiae Deorum Gentilium Libri, ed. V. Romano, Bari 1951.

11 Chaucer wspomina ją również w Opowieściach kanterberyjskich (Opowieść prawnika 75-76 i Opowieść Franklina 734-736). Innym współczesnym Chaucerowi pisarzem angielskim podjemującym ten temat był John Gower w siódmej księdze Confessio Amantis. 
ukazał niemiecki poeta Hans Sachs w Alcestis, die getreue Fürstin ${ }^{12}$. Literatura polska zawdzięcza zainteresowanie historią domu Admeta Janowi Kochanowskiemu, który przystąpił nawet do, nieukończonego niestety, tłumaczenia dramatu Eurypidesa tytułując je Alcestis męża od śmierci zastąiła. Wspomina też odwagę jej poświęcenia i zmartwychwstanie w łacińskiej elegii II 1, 35-36:

Ausa mori Alcestis pro coniuge reddita vitae est

Et durum invita morte redivit iter.

[Alkestis, która odważyła się umrzeć za męża, ożyła i wbrew śmierci wstecz przebyła ostatnią ścieżkę.]

przeł. G. Franczak

Ta interpretacja i akcent stawiany właśnie na męstwo decyzji kobiety i jej powrót do życia - konsekwencję tej odwagi, jest wysoce interesujący i odmienny od większości nowożytnych interpretacji, akcentujących raczej inne motywy postępowania żony. Jesteśmy bowiem w okresie renesansu świadkami ciekawego przeniesienia akcentu - Alkestis staje się, jeśli nie główną, to z pewnością równorzędną bohaterką opowieści o domu Admeta. Coraz większy także nacisk stawiany jest na jej miłość do męża, którego postępki i postawa w sztuce także ulegają różnym przekształceniom ${ }^{13}$. Zarówno mit, jak i szczególnie Eurypidejska wizja bohaterów coraz bardziej „uwierają” europejskich intelektualistów. Temat osobliwie wykorzystają rozliczne opery, poczynając od Alceste, ou Le triomphe d'Alcide

12 Znaną także pod tytułem Die getreue Frau Alcestis mit ihrem getreuen Manne Admeto, wydaną w Norymberdze w 1550 roku. W istocie jednak może ważniejszą rolę $\mathrm{w}$ propagowaniu postaci kochającej żony odegrał już pierwszy renesansowy dramat wzorowany na tragedii klasycznej, czyli Sofonisba G.G. Trissino (wystawiona w 1524 roku), w której główna bohaterka stylizowana jest na postaci Alkestis.

13 Szczegółowy przebieg alternacji opowieści od XVII do XX wieku patrz E.M. Butler, Alcestis in Modern Dress, „Journal of the Warburg Institute” 1 (1937), s. $46-60$. 
Jana Baptysty Lully'ego ${ }^{14}$, poprzez dzieło G.F Händla pt. Admeto, re di Tessaglia ${ }^{15}$ i chyba najsłynniejszą adaptację osiemnastowieczną Alceste Christopha Willibalda Glucka z librettem Ranieriego de' Calzabigiego $^{16}$, aż po pierwszą niemieckojęzyczną operę Alceste Antona Schweitzera, do której libretto napisał Christoph Martin Wieland ${ }^{17}$. Tragedia epoki renesansu, baroku, klasycyzmu i romantyzmu sięga z lubością po mit o Alkestis. Nie sposób wymienić tutaj ani wszystkich tytułów, ani inspiracji, nie jest to też tematem niniejszego artykułu; zagadnienie to zostało bowiem już dosyć szczegółowo opracowane przez badaczy ${ }^{18}$. Dla nas najważniejsze jest w tym miejscu, że analiza tych dzieł pokazuje nie tylko natchnienie, ale także polemikę z wizją Eurypidesa, szczególnie z postawą, motywacją i charakterem głów-

14 Wystawiona w $1674 \mathrm{r}$.

15 Opera z librettem N.F. Hayma miała swoją premierę w Londynie w $1727 \mathrm{r}$. Tutaj nadmienić jednak należy, że treść dzieła znacząco odbiega od wersji Eurypidesa. Admet Hayma jest przedstawiony jako człowiek niezwykle prawy i ofiara okoliczności, jego żona decyduje się popełnić samobójstwo bez jego wiedzy i przyzwolenia. Wszystkie postacie sztuki są na wskroś prawe, także „ta trzecia”, czyli Antygona $\mathrm{z}$ Troi, od dawna zakochana w królu, której śmierć pierwszej żony daje nadzieję na urzeczywistnienie marzenia o życiu z Admetem.

16 Wystawiona w Wiedniu w $1767 \mathrm{r}$.

17 Premiera odbyła się 28 maja 1773 r. w Weimarze.

18 Świetnym wprowadzeniem do tematu jest L.P.E. Parker, Alcestis: Euripides to Ted Hughes, „Greece \& Rome” 50 (2003), no. 1, s. 1-30 oraz tego samego autora wstęp do komentowanego wydania Alkestis (Euripides, Alcestis, ed. by L.P.E. Parker, Oxford 2007). Godne polecenia jest również opracowanie K. von Fritz, Euripides' Alkestis und ihre modernen Nachahmer und Kritiker, „Antike und Abendland” 1956, s. 27-70, gdzie szczegółowo omawiane są wersje M. Wielanda oraz postać Alkestis w Balaustrion's Adventure Roberta Browninga, a takżę sztuka Hugona von Hofmannstahla. Więcej o losach Eurypidesa we włoskim renesansie znajdzie czytelnik w: A. Pertusi, La scoperta di Euripide nel primo Umanesimo, „Italia Medioevale e Umanistica" 3 (1960), s. 101-152 i tego samego autora Il ritorno alle fonti del teatro greco classico: Euripide nell'Umanesimo e nel Rinascimento, w: idem, Venezia e L'Oriente fra Tardo Medioevo e Rinascimento, Firenze 1966, s. 205-224. Na temat anglojęzycznych oraz XX-wiecznych wersji patrz: H.M. Roisman, Alcestis, w Brill's Companion to the Reception of Euripides, ed. by R. Lauriola, K.N. Demetriou, Leiden - Boston 2015, s. 349-376. 
nej bohaterki. Paradoksalnie bowiem żona Admeta w wersji z Dionizjów roku 438 p.n.e. nie pasuje do żadnego nowożytnego wyobrażenia o ideale kochającej małżonki. Warto zatem przyjrzeć się uważnie, kim jest Alkestis Eurypidesa, bo jest to postać inna, bardziej złożona i zbudowana na wielu niezrozumiałych dla poklasycznych odbiorców niedopowiedzeniach ${ }^{19}$. Mimo że jej aktywny udział na scenie kończy się na słowie pożegnania już w wersie 391, autorowi udaje się przedstawić wielowymiarowy psychologiczny portret kobiety, która mając pełną świadomość swojej drugorzędnej pozycji w rodzinie i zachowując wszystkie stosowne dla jej statusu granice, wybija się samą heroicznością swoich cnót ponad wszystkich bohaterów sztuki. Nie pozostaje przy tym kryształowym charakterem, wzorem bez skazy, beznamiętnym uosobieniem doskonałości małżeńskiej. Tragediopisarz kreuje Alkestis, która odczuwa zarówno żal, jak i nieskrywaną niechęć do ofiary z siebie i do człowieka, za którego musi się poświęcić. To, że jako jedyna z rodziny przystała na warunki uratowania męża i króla nie znaczy, że czyni to z radością. Pokazuje siłę charakteru, ale powoli odkrywa w sztuce prawdziwe motywy swoich decyzji i pułapkę, w jakiej się znalazła. Pamiętajmy, że Admet prosi ją

19 Ann Pippin Burnett (The Virtues of Admetus, „Classical Philology” 60 (1965), no. 4, s. 240-255) słusznie zauważyła, że wybierając folklorystyczną opowieść jako fabułę swojego dramatu Eurypides świadomie i nieskrępowanie kreuje wizerunek Admeta; dokładnie to samo można powiedzieć o modelowaniu postaci Alkestis tragediopisarz tworzy tę postać zgodnie z własną wizją dramatyczną, która odbiega od bajkowego pierwowzoru. Na temat mitu i folkloru w sztuce Eurypidesa patrz: E.H. Binney, The Alcestis as a Folk-Drama, „Classical Review” 19 (1905), no. 2, s. 98-99 oraz A. Lesky, Alkestis, der Mythus und das Drama, Wien - Leipzig 1925, w języku polskim dużo o bajkowości fabuły w: J. Czerwińska, Euripides i jego twórczość, w: Literatura Grecji starożytnej. Epika - Liryka - Dramat, red. H. Podbielski, Lublin 2005, s. 830-834. Baśniowość jest także ważnym elementem tragikomicznej specyfiki utworu, ponieważ jest to jeden z głównych elementów charakterystycznych dla dramatu satyrowego (patrz: W. Steffen, Baśń ludowa w greckim dramacie satyrowym, „Meander” 8 (1953), s. 216-223 = Scripta minora selecta I, Wrocław 1973, s. 320-326). 
o oddanie życia jako ostatnią z drogich mu osób, od których mógłby oczekiwać pomocy (w. 14-15):

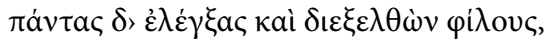

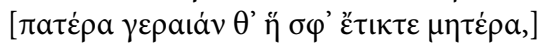

[I obszedł wszystkich, i wszystkich próbował

Przyjaciół, ojca i matkę staruszkę]

W Feraj nie ma już nikogo, kto gotów byłby umrzeć za króla - to także świadomy wybór Eurypidesa, który pokazuje, pod jaką presją znalazła się ta szlachetna, ale i pragmatyczna kobieta. Jej postawa oraz niemalże niewzruszony spokój kontrastują z zachowaniem męża: egzaltowaną rozpaczą, egoizmem, egocentryzmem i zagubieniem. W tej sztuce zresztą wszyscy przyjaciele i rodzina Admeta nie mogą dorównać Alkestis, nawet chór poddanych, który ją wysławia i opłakuje - wśród nich przecież także nie znalazł się żaden ochotnik. Zarówno sytuacja, jak i pozycja żony sprawiają, że nie ma ona właściwie żadnego wyboru (choć sama w wersie 284 będzie starała się przekonać widzów i Admeta, że jest inaczej) ${ }^{20}$. Jej powinności wynikają głównie, jak zobaczymy, z więzi określanych przez Greków jako filia. W tym miejscu należy się na chwilę zatrzymać i zastanowić nad znaczeniem tego pojęcia w epoce, jak i w samych dziełach Eurypidesa.

Studia nad teminem filia były już niejednokrotnie podejmowane przez badaczy ${ }^{21}$. Szczególnym zainteresowaniem, co zrozumiałe, cie-

20 O niemożliwości dokonania innego wyboru patrz H.P. Foley, Anodos Dramas: Euripides' Alcestis and Helen, w: Innovations of Antiquity, eds. by R. Hexeter, D. Selden, New York 1992, s. 133-134.

${ }^{21} \mathrm{Na}$ temat filia jako zagadnienia społecznego patrz: G. Herman, Ritualised Friendship and the Greek City, Cambridge 1987; D. Konstan, Friendship in the Classical World, Cambridge $1997 \mathrm{z}$ dalszą bibliografią. Problem filia w tragedii omówiony został szczegółowo w: E.S. Belfiore, Murder among Friends: Violation of Philia in Greek Tragedy, Oxford 2000. 
szy się rozumienie tego pojęcia w pismach Platona i Arystotelesa ${ }^{22}$. Ujmując problem w wielkim skrócie powiedzieć można, że Grecy określali w ten sposób przyjaźń, związek oparty na życzliwości i przede wszystkim - lojalności.

Znaczenie terminu w samej Alkestis szczegółowo analizował już S.L. Schein ${ }^{23}$, którego ogólne wnioski warto tutaj pokrótce przytoczyć. Pamiętajmy, że filia jest przyjaźnią w społeczeństwie kultury wstydu, gdzie raz zadzierzgnięte więzi gwarantowane są honorem, ale jest także wyrazem opozycji pomiędzy tym, co obce, a zatem wrogie, i tym, co swoje, bliskie i przez to drogie ${ }^{24}$. U Eurypidesa termin może określać związki pomiędzy gospodarzem a gościem i w tym sensie jest logiczną konsekwencją innego ważnego i nienaruszalnego przymierza, określanego jako xenia. Jest także używany na oznaczenie więzi międzyludzkich w szeroko pojętej rodzinie, obejmującej nie tylko małżonków i dzieci, ale także wszystkich domowników, a zatem również podległą służbę, i w tragedii najczęściej tłumaczona jest polskim terminem „miłość". Takie relacje w oikos są oparte właśnie w pierwszym rzędzie na lojalności, szacunku i przywiązaniu, emocje zaś, choć w tragedii zawsze wyeksponowane, są jedynie

22 W ostatnich dziesięcioleciach zagadnienie doczekało się wielu opracowań, patrz przykładowo: J.M. Cooper, Aristotle on the forms of friendship, „Review of Metaphysics” 30 (1977), s. 619-648; idem, Friendship and the Good in Aristotle, „Philosophical Review” 86 (1977), s. 290-315; idem, Aristotle on friendship, w: Essays on Aristotle's Ethics, ed. by A.O. Rorty, Berkeley 1980, s. 301-340, A.W. Price, Love and Friendship in Plato and Aristotle, Oxford 1989, K. Rogers, Aristotle on loving another for his own sake, „Phronesis”, 39, 1994, s. 291-302, P. Schollmeier, Other Selves. Aristotle on Personal and Political Friendship, New York 1994, S. Stern-Gillet, Aristotle's Philosophy of Friendship, Albany 1995, J. Whiting, The Nicomachean Account of Philia, w: Blackwell Guide to Aristotle's Nicomachean Ethics, ed. by R. Kraut, Cambridge 2006, s. 276-304.

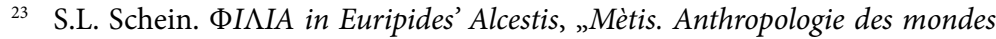
grecs anciens" 3 (1988), no. 1-2, s. 179-206, oraz G.R. Stanton, Philia and Xenia in Euripides 'Alcestis', „Hermes” 118 (1990), s. 42-54.

24 Najlepiej widać to $\mathrm{w}$ wersach Theognisa (1,599-600), poety, który jako pier-

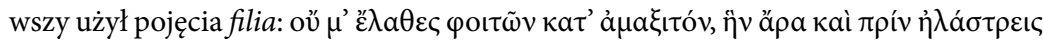

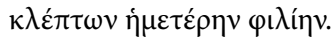


konsekwencją tych trzech. Filia w epoce klasycznej nie określa żadnych romantycznych uniesień i nawet gdy analizujemy pełne pasji zapewnienia Admeta o miłości do małżonki, nie możemy odczytywać w nich tego, co współczesny czytelnik w naturalny sposób chciałby pod tymi zapewnieniami rozumieć ${ }^{25}$. W Alkestis przymiotnik filos zastosowany jest po raz pierwszy właśnie w kontekście zobowiązań wynikających z gościny - Apollon nazywa pałac Admeta „najmil-

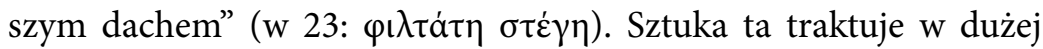
mierze właśnie o sprzecznościach i wyzwaniach jakie niesie ze sobą filia $^{26}$. Bóg, chcąc dopełnić powinności wynikających z przyjaźni z gospodarzem, daje mu możliwość ucieczki przed śmiercią, ale tym samym doprowadza do rozbicia filia w jego rodzinie: Admet wyrzeka się własnych rodziców, traci żonę, a dzieci i domownicy zostają osieroceni. Oczywiście Apollon wie (w. 65-71), że przybędzie Herakles, wobec którego król okaże należne względy wynikające z xenia i filia, ale czy to uratuje rodzinę? Eurypides każe nam wątpić w odbudowanie „domu Admeta”. Alkestis co prawda wraca, ale milczy i nie wiemy, co stanie się, gdy w końcu przemówi - tragediopisarz pozostawia tę kwestię niedopowiedzianą. Związek z ojcem zostaje natomiast definitywnie zerwany. Symptomatyczne jest, że bóstwo

25 Wydaje się, że za powiązanie ofiary Alkestis z miłością stricte małżeńską (a także bezpośrednio z problemem miłości określanej jako eros i agape) odpowiada Platon. W Uczcie omawia między innymi jej poświęcenie w kontekście związku Patroklosa i Achillesa, przyznając temu ostatniemu wyższość (180a 4-180b 5). W innym jednak miejscu tego samego dialogu kładzie, podobnie jak Eurypides, nacisk na filia Alkestis, która przewyższa erosa (179b 4-179d 1), w jeszcze innym zaś miejscu podaje jej ofiarę za przykład śmierci wynikającej z pragnienia pośmiertnej sławy (kleos): 208c 2-208e 1). O problemie „miłości” i obowiązku w tej tragedii patrz: C.M.J. Sicking, Tragédie d'amour ou tragédie du devoir?, „Mnemosyne” 41 (1967), s. $155-174$.

26 Co nie przeczy, a wręcz dopełnia teorię N. Rabinowitz, że w sztuce tej istotną rolę odgrywa rola Alkestis jako zastawu xenia pomiędzy parami mężczyzn: Admetem i Apollonem, Apollonem i Thanatosem i w końcu Admetem i Heraklesem (patrz N. Rabinowitz, Anxiety Veiled: Euripides and the Traffic in Women, Ithaka - London 1990, s. 90). 
już w samym prologu opowiada, jak zarówno rodzice, jak i przyjaciele (filoi), na których lojalność i przywiązanie Admet liczył, zawodzą. Oni nie mogą mieć nadziei na odbudowanie serdecznych więzi z królem. W objęcia męża powraca jedynie Alkestis, ale szybko rodzi się pytanie, czy zauważy ona i wyciągnie konsekwencje z tego, że Admet, pomimo solennych zapewnień o swojej miłości, nie dotrzymał warunków filia wobec niej samej.

Dochodzimy tu jednak do problemu bardzo ważnego, a mianowicie tego, w jaki sposób Alkestis stała się uosobieniem miłości małżeńskiej, skoro sama konsekwentnie unika jakiegokolwiek zapewnienia, że miłuje swojego męża. O tym, że właśnie filia jest jedną $\mathrm{z}$ największych cnót Alkestis, mówi Admet w pełnym tragicznego patosu wersie (w. 279):

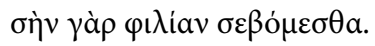

[Tak twoją miłość czcimy.]

Przesada i egzaltacja typowe dla niemalże każdej wypowiedzi króla są w tych słowach widoczne nie tylko w trącących fałszem stwier-

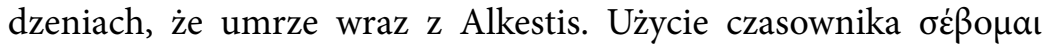
(czcić, adorować, wyznawać, odczuwać lęk przed bogiem), którego zakres semantyczny związany jest $\mathrm{z}$ kultem, może zaskakiwać - to jakby heroizacja filia Alkestis. Admet czci miłość rodzinną kobiety, ale słowa te, podkreślmy to jeszcze raz, nie są osobistym wyznaniem miłości małżonka. Zanim padnie ta kwestia, kilkadziesiąt wersów wcześniej w stasimonie 1, na chwilę przed tym, gdy królowa pojawi się po raz pierwszy na scenie, to chór powie (w. 231):

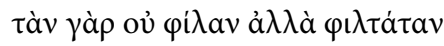

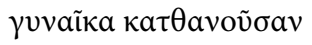

[bo nie kochaną a najukochańszą zobaczysz żonę, jak dzisiaj

$\mathrm{Na}$ oczach twoich umiera.] 
Poddani, których reprezentuje śpiewająca i tańcząca grupa na orchestrze, mówią tutaj o emocjach i uczuciach, jakie budzi w nich królowa. Jest to ich własna, publiczna deklaracja tego, jak ważna i bliska jest dla nich pani. W tych wersach wyrażają także życzenie, by władca dostrzegł, jaką absolutnie wyjątkową żonę traci. Chór uprzedza fakty i przygotowuje widzów na scenę agonu pomiędzy Admetem i Alkestis, scenę, w której małość króla i wielkość królowej będą najlepiej widoczne. To ona jest „najukochańsza”, to wobec niej Admet powinien żywić najszlachetniejsze uczucie filia, w stopniu najwyższym, na jakie zasługuje. Mąż określi ją tak dopiero pod koniec sztuki (w. 1133), gdy w kobiecie przyprowadzonej przez Heraklesa rozpozna zmarłą. Okoliczności jednak, do czego wrócimy później, każą wątpić w szczerość tego wyznania. Alkestis jest natomiast lojalna i $z$ determinacją traktuje swoje obowiązki wynikające z filia wewnątrz rodziny. Motyw jej poświęcenia jest jasny i dobitnie wyrażony w tragicznej scenie pożegnania z małżeńskim łożem, symbolem jej życia, w którym stała się i żoną, i matką. Zamiast oczekiwanego przez nas wyznania miłości i przywiązania do męża Alkestis mówi (w. 177-181):

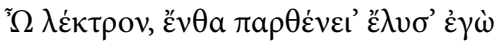

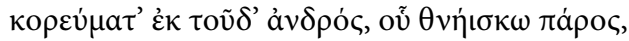

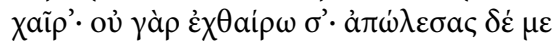

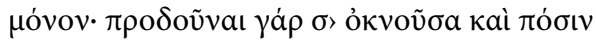
$\theta v \eta \dot{\iota} \kappa \omega$

[Łoże, na którym pas dziewiczy zdjęłam Dla tego męża, za którego umrę, Żegnaj - bo wcale cię nie nienawidzę Mnie jedną tylko gubisz. Nie zdradziwszy Ciebie ni męża umieram]

A więc przede wszystkim zapewnia, że nie nienawidzi, tylko tyle i aż tyle. Reszta wypowiedzi jest wyrazem swego rodzaju gniewu 
lub rozczarowania. Mocnemu czasownikowi $\bar{\chi} \chi \operatorname{\alpha i} \rho \omega^{27}$, typowemu raczej dla określeń używanych wobec wroga, towarzyszy kolejny termin typowy dla słownictwa wyrażającego idee polityczne, państwowe czy wojskowe $\pi \rho \circ \delta i \delta \omega \mu^{28}$, tu oczywiście w znaczeniu „nie zdradziłam". Tym wyznaniem podkreśla Alkestis, że dotrzymała wierności zasadom wynikającym z filia w rodzinie, że do śmierci za męża zmusza ją lojalność i dopełnienie powinności, jakie wzięła na siebie, gdy po raz pierwszy położyła się w łożu, do którego kieruje te słowa ${ }^{29}$. Ale płacząc dodaje jednak bardzo symptomatyczne zdanie (w. 181-182):

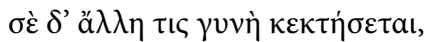

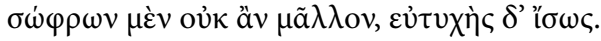

[A ciebie mieć będzie inna,

Nie bardziej cnotliwa, a równie szczęśliwa ${ }^{30}$.]

27 Odpowiedzią i dopełnieniem tego wersu jest kwestia wyśpiewana przez chór

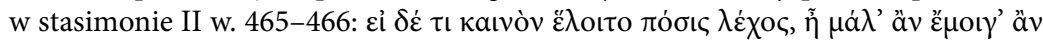

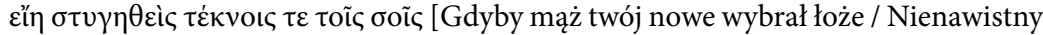
będzie mnie i dzieciom] - chór używa jednak bardziej uniwersalnego czasownika

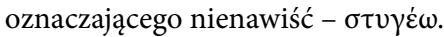

28 Podstawowe znaczenia czasownika to: ustąpić pola, poddać się, zdradzić.

29 Problem zdrady w sztuce zasługuje na osobne potraktowanie. Już W.D. Smith w The Ironic Structure in Alcestis, „Phoenix” 14 (1960), s. 130 zauważył, że sztuka w wysokim stopniu dotyczy właśnie zdrady i użycie różnych czasowników na jej określenie, szczególnie $\mathrm{w}$ powiązaniu $\mathrm{z}$ wyrazami oznaczającymi wstyd za każdym razem modyfikuje „ironiczny” wizerunek postaci. Stwierdzenie Alkestis (w. 179-181) ma swoje zaskakujące echo wypowiedzi w służebnej cytującej Admeta (w. 201-202):

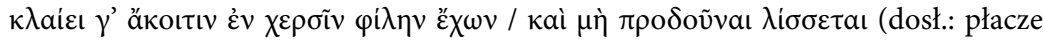
w ramionach trzymając drogą żonę i błaga, by go nie zdradzała). Ta paralela, relacjonowana zresztą widzowi przez tę samą służebną, ma nie tylko swój wydźwięk ironiczny, ale także absurdalny i prowokacyjny. Jest to element swego rodzaju marginalizacji ofiary Alkestis dokonywanej w tekście dramatu kilkakrotnie przez Admeta, o czym poniżej.

${ }^{30}$ W tym miejscu odchodzę od przekładu J. Łanowskiego, który zmienia sens wersu. 
I w tej jednej wypowiedzi ujawnia cały swój żal do Admeta, po którym spodziewa się właśnie zdrady. Wers antycypuje zresztą dość niespotykaną w greckiej kulturze prośbę kobiety o pośmiertną wierność małżonka. Wzajemne relacje pomiędzy Alkestis a Admetem najwyraźniej widoczne są w najsłynniejszym agonie sztuki w epeisodionie II (238-434) ${ }^{31}$. Królowa kona i doznaje mistycznych wizji przechodzenia z życia do śmierci, o czym pełna przerażenia mówi w urywanych zdaniach. Pierwsza część małżeńskiej rozmowy jest jednak celowo niespójna, oboje się albo wzajemnie nie słyszą, albo słyszeć nie chcą. Admet koncentruje się jedynie na swoim bólu i cierpieniu. Po każdej wypowiedzi żony mężczyzna odpowiada używa-

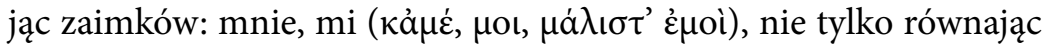
swoje i jej cierpienie, ale właściwie ignorując zarówno jej strach, jak i głębsze znaczenie słów. Pierwsza wizja Alkestis dotyczy rzeczy, za którymi tęskni, za słońcem i światłem dnia, chmurami pędzącymi po niebie oraz domem rodzinnym i dzieciństwem ${ }^{32}$, druga natomiast to drastyczne sceny porywania jej przez siły podziemne przed oblicze skrzydlatego Hadesa. Alkestis wybudza z transu dopiero wspomnienie dzieci, gdy wypowiada słowa pożegnania $\mathrm{z}$ nimi, dochodzi do siebie i mobilizuje siły, by zapewnić im przyszłość. Ostatnia stychomityczna część agonu (w. 371-391) jest jeszcze bardziej zaskakująca. W pełni świadoma królowa najpierw oddaje mężowi pod opiekę dzieci, żądając kilkakrotnie zapewnień z jego strony i, jakby mimo

31 Odmienną i bardzo ciekawą interpretację agonów pomiędzy Admetem i Alkestis oraz Admetem i Feresem przedstawiła J. Czerwińska w: Agony racji w „Alkestis” Eurypidesa, „Collectanea Philologica” 1 (1995), s. 91-102, gdzie opowiada się za protagorejskim odczytaniem dyskusji w sztuce i stoi na stanowisku, że zderzenie trzech racji (prawd) w sztuce Eurypides nakreślił tak, by wykazać względność każdej z nich. Na temat wpływu sofistyki oraz ambiwalencji argumentów w Alkestis patrz. rozdział piąty monografii D. Conacher, Euripides and the Sophists, London 1998.

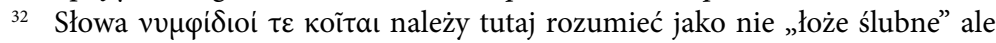
posłanie, na którym spała w Jolkos jeszcze jako młodziutka narzeczona. Jej łoże małżeńskie to to, na którym zanosiła się płaczem i stoi ono w domu jej męża, w pałacu w Feraj. 
wszystko mu nie ufając, powołuje je na świadków przysięgi, a następnie dystansuje się od wszystkich dalszych wypowiedzi męża. Nie zdobywa się na żaden gest czułości wobec niego, rzeczowo odpowiadając na biadolenia. Można nawet odnieść wrażenie, że są to cierpkie i cięte riposty ${ }^{33}$. Stoi to $\mathrm{w}$ dużej sprzeczności $\mathrm{z}$ obrazem, jaki rysuje przed naszymi oczami służebna w wersach 152-198, gdzie Alkestis czule żegna się z dziećmi i domownikami (w. 189-195):

$\pi a \tilde{\delta} \delta \varepsilon \varsigma \delta \grave{\varepsilon} \pi \dot{\varepsilon} \pi \lambda \omega \nu \mu \eta \tau \rho \grave{\varsigma} \varsigma \dot{\varepsilon} \xi \eta \rho \tau \eta \mu \varepsilon \dot{\varepsilon}{ }^{\prime}$

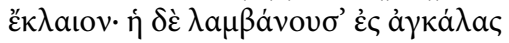

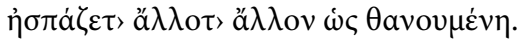

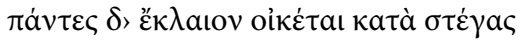

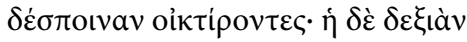

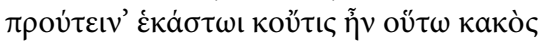

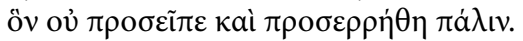

[Dzieci u szaty matki uczepione Płakały. Ona brała je w objęcia Pieszcząc na przemian, żegnając przed śmiercią. I wszyscy słudzy domowi płakali Żałując pani. Ona wszystkim rękę Ściskała. Każdy, nawet najpodlejszy, Mógł z nią zamienić słowa pożegnania.]

Ta intymna scena domowa nie ma swojego odpowiednika w pożegnaniu z królem. Jest tylko jeden moment w sztuce, gdy sama Alkestis pokazuje mężowi, na czym polega jej filia i staje się to właśnie

33 Szczególnie czterowiersz 380-384:

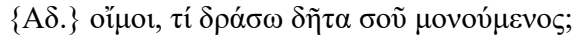

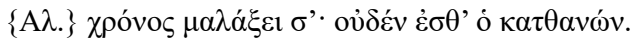

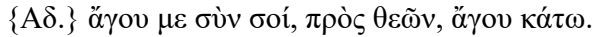

$\{\mathrm{A} \lambda.\} \dot{\alpha} \rho \kappa о \tilde{v} \mu \varepsilon v \dot{\eta} \mu \varepsilon \tilde{\iota} \varsigma$ oi $\pi \rho \circ \theta v \dot{\eta}$

[Ad. Biedny, co pocznę sam jeden bez ciebie?

Al. Czas cię uleczy. Umarły jest niczym.

Ad. Weź mnie ze sobą, na bogów, weź w Hades!

Al. Starczy, że ja tu za ciebie umieram.] 
po Admetowych słowach o czczeniu jej miłości (w. 279). Królowa zwraca się do męża z zamiarem wymuszenia na nim bezwarunkowej opieki nad dziećmi. Jeśli do tej pory nie znaliśmy w pełni motywów, dla których zgodziła się umrzeć za męża (dzieje się to przed rozpoczęciem sztuki), teraz dowiemy się tego z błyskotliwej przemowy, majstersztyku sztuki oratorskiej z genialnie wkomponowanym szantażem emocjonalnym odegranym przy świadkach: domownikach i dzieciach. Antycznemu widzowi mogło się wydawać, że Alkestis posuwa się za daleko, zmusza męża do permanentnego wdowieństwa i robi to, nie bacząc na kłopotliwą sytuację, w jakiej go stawia, wypunktowując wszystkie swoje zasługi. Można się spodziewać, że matka umierająca zamiast ojca ufa mu na tyle, by nie domagać się publicznych przysiąg dotyczących przyszłości dzieci, ale nikt lepiej od Alkestis nie zna przecież bezmiaru egoizmu Admeta. Najpierw zatem dowiadujemy się, jaki był motyw jej decyzji - to dotrzymanie wierności ideałowi dobrej żony, która oddaje pierwszeństwo mężowi

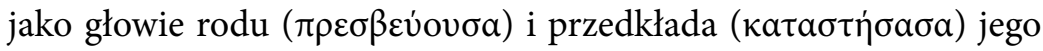
życie nad swoje. Jest to prosty rachunek każdej greckiej kobiety, istoty drugiego planu. Nie ma mowy o żadnej miłości, jest jedynie realna ocena swojej roli w oikos. Następnie Alkestis opisuje wspaniałą przyszłość, jaka mogła ją czekać jako władczynię Feraj po śmierci Admeta. Wybiera przy tym najbardziej dla siebie korzystny scenariusz, w którym swoją rękę wraz z królestwem oddaje jednemu $\mathrm{z}$ poddanych, nie zaś równorzędnemu królowi lub księciu $\mathrm{z}$ innego królestwa i nie przestaje sprawować realnej władzy w „przepełnionym błogosławieństwem domu" ( $\delta \tilde{\omega} \mu \alpha$ ö $\lambda ß o v)$. Jednak już w następnym zdaniu ujawnia prawdziwy motyw swojej śmierci za Adme-

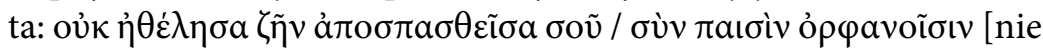
chciałam życia $\mathrm{z}$ dziećmi sierotami po wydarciu ciebie] ${ }^{34}$. Alkestis nie jest sama i nie decyduje jedynie o sobie - nowy tesalski mąż, chcący niewątpliwie spłodzić własnych następców, byłby

34 Tutaj odchodzę minimalnie od tłumaczenia J. Łanowskiego, ponieważ dosłowne sformułowanie jest kluczowe dla interpretacji ustępu. 
jeszcze większym zagrożeniem dla syna i córki królowej niż nowa żona Admeta. Nie tylko los zwyczajnej greckiej owdowiałej obywatelki z dziećmi jest ciężki, niepewna przyszłość czeka także młode królowe, czego najlepszym przykładem sytuacja Penelopy w domu pełnym agresywnych zalotników. Alkestis jest pragmatyczna, celem każdej jej wypowiedzi pozostaje postawienie męża w sytuacji emocjonalnego dłużnika. Sięga zatem po kolejny mocny argument - postawę teściów. Przypomina, że „ten, który go spłodził i ta, która go urodziła" (w. 290), zdradzili ( $\pi \rho \circ \delta i \delta \omega \mu)$, choć byłoby czynem

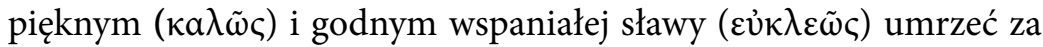
syna. Rodzice nie mają obowiązku poświęcić się za dzieci i Alkestis doskonale o tym wie. Ofiara z życia jednego z nich byłaby dowodem takiej samej dzielności i lojalności jak czyn żony. Jedynie pragmatyzm i dobro oikosu podpowiadają, że ich śmierć byłaby mniejszym złem niż odejście króla lub królowej, szczególnie że oboje są już starzy i niezdolni do spłodzenia nowego władcy. Ten argument wykorzystuje umierająca i wykazuje, że akt jej dobrowolnej śmierci jest dowodem najwyższego oddania wobec oikos (filia), jakiego nie podjęli się nawet rodzice, i stawia swoją cnotę wyżej niż ich. Ta wypowiedź będzie miała w sztuce ważne i nieoczekiwane konsekwencje, do czego wrócimy. Wyczerpawszy listę swoich zasług dla Admeta, bohaterka żąda następnie zapłaty, przy czym użyty w tym miejscu

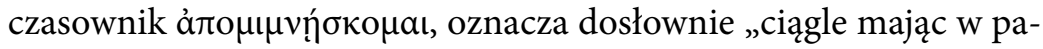
mięci potrzebę odpłaty”. Właśnie - mąż ma obowiązek spłacać ten dług wdzięczności ciągle pamiętając, dlaczego to robi, ale cokolwiek by uczynił, jak zaznacza żona, i tak nie zrównoważy jej poświęcenia (w. 300-301). Alkestis wywołuje w małżonku poczucie winy i długu gwarantujące, że przychyli się do jej niecodziennej prośby ${ }^{35}$. W następnych wersach błaga go, by nie poślubił żadnej innej kobiety ze względu na dobro dzieci. I po raz kolejny wracamy do najważniej-

35 Interesującą koncepcję dotyczącą kontroli nad śmiercią, a co za tym idzie, kontroli nad Admetem opracowała J.J. Dellner, Alcestis' Double Life, „The Classical Journal" 96 (2000), 1, s. 1-25. 
szego motywu postępowania królowej i źródła jej heroizmu. Syn i córka pary są obecni na scenie, zabieg dość rzadki w greckiej tragedii $^{36}$. Słyszą, gdy matka zaklina ojca i mówi, że macocha będzie dla nich „wrogiem gorszym od żmii” (w. 310). Następnie jednak matka zwraca się bezpośrednio do dziewczynki, choć sens słów i złowrogi przekaz ma dotrzeć przede wszystkim do ojca (w. 313-319):

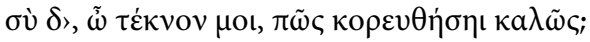

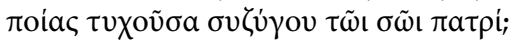

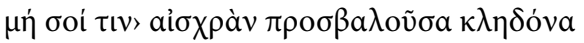

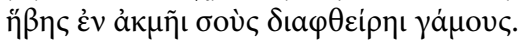

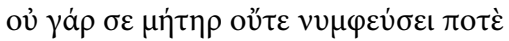

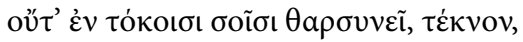

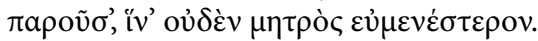

[Lecz ty córeczko, gdy zostaniesz panną,

Jaką ci będzie małżonka ojcowska?

Może ci szpetne narzuci przezwisko,

Zniszczy ci w kwiecie młodości zamęście?

To już nie matka cię odda mężowi

I nie wspomoże, dziecko, w dzień połogu.]

Alkestis mówi o dwóch zagrożeniach. Macocha wymyśli jakieś

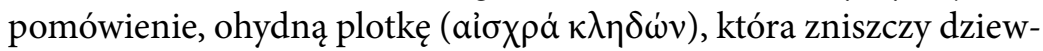
czynie szanse na założenie rodziny. Jeśli jednak tak się nie stanie, to i tak opuszczona przez matkę mężatka może nie przeżyć połogu - dosyć niecodzienny argument w ustach królowej, pochodzącej z Jolkos, której matka z pewnością nie przybyła do Feraj asystować przy porodach. Jest to typowa cecha Eurypidejskiej tragedii, nieco mieszczański element realizmu i greckiej codzienności wprowadzony do królewskich pałaców ${ }^{37}$. Te dwa przykłady trudności czyhają-

36 Obecność dzieci w sztuce omawia M. Dyson w Alcestis' Children and the Character of Admetus, „Journal of Hellenic Studies” 108 (1988), s. 13-23, ale trudno się zgodzić z jego głównym postulatem, że Alkestis nie umiera za oikos i dzieci (s. 15).

37 Pomysł pokazania królowej spieszącej pomóc córce przy porodzie wykorzystał Eurypides jeszcze w Elektrze 998-1146. Tam dziewczyna udając połóg zwabia 
cych na osierocone dziewczynki trafiają do wyobraźni ateńskiej publiczności, odwołują się do rodzinnych doświadczeń, gdzie związki małżeńskie zawierano zazwyczaj w bliskim sąsiedztwie i kobiety pozostawały w kontakcie, widując się nie tylko na misteriach i świętach, ale nawet wspólnie pracując i organizując małe przyjęcia w gynajkejonach. Troska o dziewczynkę, najmniej istotnego członka greckiej rodziny, jest dziwna. Królowa umiera, by jej dzieci mogły wychować się w obecności i pod opieką ojca-władcy, ale w ostatnich chwilach orientuje się, że jej ofiara zapewni bezpieczeństwo wyłącznie synowi, że na córkę dalej mogą spaść niewyobrażalne nieszczęścia. To dlatego właśnie wybudza się z hadesowego transu, by w finalnej pieśni wymusić ochronę dla dziewczynki.

Slater ma oczywiście rację, pisząc o nietypowej wręcz trosce o sieroty w sztuce Eurypidesa ${ }^{38}$. W jego omówieniu główną rolę odgrywą jednak socjopolityczne problemy związane z sytuacją chłopców, których ojcowie polegli w obronie ojczyzny, i powiązanie tego zagadnienia z kwestiami poruszanymi przez tragika. Eurypides natomiast nie koncentruje się wyłącznie na losie Eumelosa, ale także, może nawet bardziej, na niebezpieczeństwach grożących córce Alkestis. Co więcej - na dzieci Admeta czyhają zupełnie inne zagrożenia niż te wiszące nad „sierotami wojny”. Jedną z centralnych kwestii sztuki pozostają konsekwencje, z jakimi muszą zmierzyć się dzieci po śmierci matki, nie ojca, rzecz w ateńskim dyskursie politycznym niemalże niespotykana. Perimele, której imię w sztuce nawet nie pada, choć obecna jest na scenie, milczy. Lament nad matką podnosi tylko syn, Eumelos i jest to w historii greckiego dramatu jedyny taki tren - męska pieśń przy zwłokach. Dziecko w obecności ojca i służby wypowiada zaska-

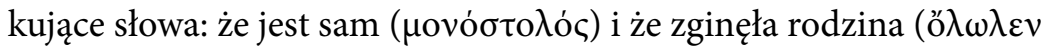
oĩkoৎ). Szczególnie to ostatnie jest zdumiewające, Alkestis umiera

Klitajmestrę do swojej chaty, by ta spełniła przepisane ofiary po narodzinach dziecka. Matka, choć zaaranżowała Elektrze poniżające małżeństwo i wygnała ją z pałacu, nie ociąga się z przybyciem do córki w połogu.

38 N.W. Slater, Euripides: Alcestis, London 2013, s. 38-40. 
przecież by oikos ratować. Ale taki właśnie był od początku zamiar Eurypidesa, pokazanie, że paradoksalnie to szlachetna i pełna filia królowa jest centrum i warunkiem istnienia „domu Admeta”. Dzieje się to na różnych poziomach sztuki, w sferze psychologicznej i werbalnej. W scenie poprzedzającej żałobną pieśń Eumelosa wydarzyło się coś niespotykanego nie tylko w literaturze, ale tym bardziej greckim w życiu codziennym: rodzice niejako oficjalnie zamienili się rolami. Zauważono już, że scena, w której Alkestis powierza dzieci Admetowi, nosi cechy oficjalnego schematu adopcji ${ }^{39}$, aktu przekazania dziecka, którego mógł dokonać jedynie męski członek rodziny. Admet przyjmuje dzieci z rąk żony i słyszy słowa (w. 377):

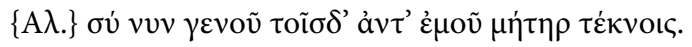

[Al. Bądź teraz dzieciom w moje miejsce matką.]

Dziwna to adopcja, nie tylko dlatego, że oddającą jest kobieta, ale także dlatego, że przyjmujący dzieci mężczyzna ma stać się matką. Na paradoks i odwrócenie ról w rodzinie jest jednak widz przygotowywany od początku sztuki. Alkestis konsekwentnie opisywana jest w kategoriach męskich, a nie kobiecych cnót i wartości: dzielności

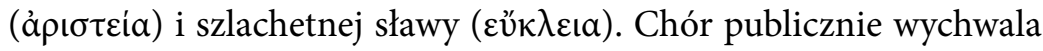

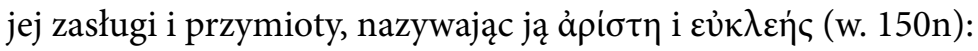

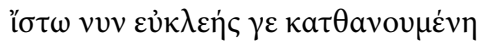

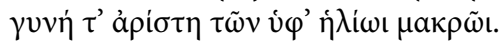

[Niech wie, że sławnie umrze, ta najlepsza

Z kobiet pod słońcem, na szerokim świecie.]

Na co służąca, jakby spodziewając się zarzutu niestosowności użycia epitetu „ariste”, dopowiada natychmiast:

39 C.A.E. Luschnig, Euripides' Alcestis and the Athenian Oikos, „Dioniso” 60 (1990), s. 21. N.W. Slater, Euripides..., s. 55. 


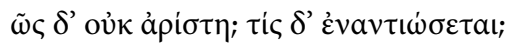

[Czyż nie najlepsza? Czy ktoś się sprzeciwi?]

Zwrócono już uwagę, że pod względem liczby określeń ariste wobec kobiety sztuka ta nie ma sobie równych $(9 \text { razy! })^{40}$. Jednak podobnie niezwykły epitet wobec niewiasty to $\varepsilon \dot{\kappa} \kappa \varepsilon \dot{\eta} \varsigma, \mathrm{w}$ tragedii używa go zresztą tylko Eurypides. Sława kobiety, przynajmniej za jej życia, nie powinna wychodzić poza granice domu i nie jest to kategoria, którą ocenia się rodzinne zasługi. Alkestis tymczasem jest nie tylko publicznie gloryfikowana przez chór i męża, ale także umiera na scenie. Ma to miejsce zapewne w łożu wtoczonym na enkyklemacie, dzięki czemu zaraz po jej śmierci możemy być świadkami sceny adoracji zwłok na marach - prothesis z Eumelosem w roli głównej ${ }^{41}$. W przeciwieństwie do męża królowa sama nie szuka ani sławy, ani nawet akceptacji, obecność chóru jest przez nią niemalże niezauważona.

Tymczasem Admet wraz z rozwojem fabuły przybiera coraz więcej cech niemęskich. Jeszcze w prologu przedstawiany jest jako król godny przyjaźni Apollona, następnie jako nieszczęśliwy małżonek (do wersu 244, gdy po raz pierwszy chór poddaje w wątpliwość sens dalszej egzystencji władcy). Od momentu pojawienia się na scenie i rozmowy z umierającą postać Admeta zostaje poddana bezpośredniej ocenie widowni. Prośba, a właściwie żądanie żony, by nie poślubiał innej kobiety demaskulinizuje władcę ${ }^{42}$, pozbawia go podstawowego prawa greckiego kyriosa, nie tylko do nieskrępowanej prokreacji, ale przede wszystkim do samodzielnie podejmowanych decyzji. Co ważniejsze, perspektywa, jaką sam Admet przedstawia widowni, że będzie dzielił łoże z posągiem przypominającym Al-

40 K. Bassi, The Actor as Actress in Euripides' Alcestis, „Themes in Drama” 11 (1989), s. 25.

${ }^{41}$ O przestrzeni scenicznej w Alkestis patrz: C.A.E. Lusching, Imaginary Spaces in Alcestis and Medea, „Mnemosyne” 45 (1992), no. 1, s. 19-44.

42 Tego samego zdania jest M. Padilla w Gifts of Humiliation..., s. 19. 
kestis, nie jest wyłącznie elementem budowania ironii czy symbolem różnych rytualnych przemian ${ }^{43}$, to przede wszystkim motyw, dzięki któremu Eurypides zwraca naszą uwagę na seksualność bohatera i ograniczenia, jakie nakłada na niego zobowiązanie żony. Szczególnie wizja snów erotycznych i pośmiertnego połączenia ciał w cedrowej trumnie (w. 365) obnażają zmysłowość króla. Alkestis nie wymaga od niego bezwzględnego celibatu, a jedynie odstąpienia od zwyczajowego poślubienia kolejnej kobiety. Mężczyzna zobowiązuje się jednak do zupełnej rezygnacji z obcowania $\mathrm{z}$ innymi niewiastami - w greckiej rzeczywistości społecznej i moralnej deklaracja ta wydaje się jeśli nie absurdalna, to przynajmniej bardzo dziwaczna. W omawianej sztuce Admet jest ponadto postacią bardzo skoncentrowaną na cielesnym aspekcie małżeństwa. Jego reakcja na inne kobiety (w. 950-953) i zawoalowaną postać przyprowadzoną przez Heraklesa także jest symptomatyczna (w. 1037-1169): z jednej strony prosi bohatera, by ją zabrał, z drugiej zaś uważnie taksuje dziewczynę, zwraca uwagę na jej wzrost i podobieństwo do Alkestis oraz przedstawia wizję napastliwych młodzieńców, którzy mogliby ją skrzywdzić. Wobec kleos i arete Alkestis - taki właśnie mężczyzna,

43 Posąg Alkestis w łożu Admeta jest przedmiotem wielu dociekań i interpretacji badaczy. U. von Wilamowitz-Moellendorff w Griechische Tragödien, Bd. 3, Berlin 1906, s. 91-92, zwrócił uwagę na kwestię powiązania posągu Alkestis z historią Laodamii i podobizny Protesilaosa (także użytej przez Eurypidesa za podstawę zaginionej tragedii). Uczeni szczególnie skupiają się na podobieństwach idei posągu pośmiertnego do kollosoi, rzeźb pogrzebowych chowanych zamiast ciała w przypadkach, gdy normalny pochówek był niemożliwy (np. śmierci na morzu), patrz.: J.-P. Vernant, Du double à l'image - Figuration de l'invisible et catégorie psychologique du double: le colossos, w: idem: Mythe et pensée chez les Grecs, Paris 1985, s. 325-328; C. Segal, Euripides and the Poetics of Sorrow, Durham - London 1993, s. 37-50. Na temat motywu posągu Alkestis w kontekście społecznego odbioru rzeźb funeralnych i innego typu podobizn osób prywatnych patrz N. Slater, Euripides..., s. 57-61. O specyficznym toposie kontaktów fizycznych z rzeźbami w literaturze greckiej patrz: S. O'Bryhim, The Economics of Alagmatophilia, „The Classical Journal" 110 (2015), no. 4, s. 419-429. 
uwięziony pomiędzy własną cielesnością a strachem przed oceną innych - stopniowo pozbawiany zostaje cnót głowy rodu.

Po śmierci Alkestis, zgodnie z tym, co zapowiedział Eumelos, oikos Admeta już nie istnieje. Jego upadek dopełnia scena przybycia Feresa na pogrzeb synowej i wyrzeczenie się ojca przez syna. Starzec przychodzi przynosząc bogate dary grobowe i, chwaląc postawię Alkestis, daje ją za dobry przykład innym kobietom (w. 623-625). Król odtrąca jednak ten pokojowy gest i wypowiada pierwsze wstrząsa-

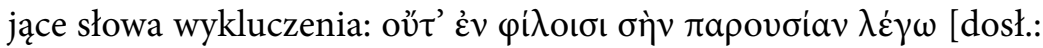
nie uważam, że w twojej osobie przybywa jeden z moich filoi]. Dalej następuje próba przeniesienia winy za odrzucenie, wykazanie, że ojciec niegodny jest syna (w. 636-641):

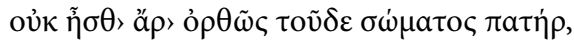

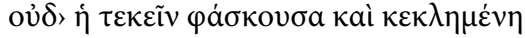

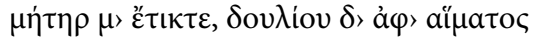

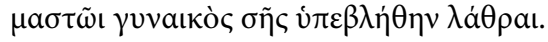

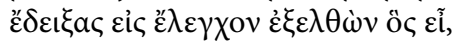

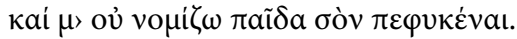

[Płaczesz? Nie jesteś może moim ojcem?

Czyż nie ta, co się zwie i którą zowią

Matką, zrodziła mnie? - Z krwi niewolniczej

Czy podrzucono mnie na pierś twej żony?

Tyś mi pokazał, dowiódł, jaki jesteś, I nie uważam, żebym był twym synem!]

Żaden inny bohater greckiej tragedii w tak perwersyjnie dosłowny sposób nie wyrzeka się rodzica ${ }^{44}$. Admet mówi, że starzec

${ }^{44}$ W tym miejscu zaznaczyć należy, że opinia E.M. Thury, Euripides' Alcestis and the Athenian Generation Gap, „Arethusa” 21 (1988), s. 197-214), że wyrzeczenie się rodziców zostało przez Alkestis wymuszone w pożegnalnej mowie, jest z punktu widzenia tekstu nieuzasadniona, podobnie jak teza, iż postępowanie Admeta mogło być przez publiczność przyjęte ze zrozumieniem ze względu na swego rodzaju konflikt pokoleń. Należy podkreślić, że król nie posuwa się jednak do wyrzeczenia ojcowizny (w. 737-738), którą stanowi przecież całe królestwo Feraj. 
z powodu tego, jak się zachował i co tym samym pokazał (albo nie pokazał), nie może być osobą, która go spłodziła. Król przedstawia siebie jako moralnie przewyższającego Feresa, zupełnie ignorując to, że to za niego, a nie za ojca umarła Alkestis, co w następnej części agonu brutalnie przypomni mu lżony starzec. Taka manipulacja ma miejsce jeszcze w kolejnych wersach, aż dochodzimy do punktu kulminacyjnego - wyrażenie gotowości przyjęcia zmarłej Alkestis

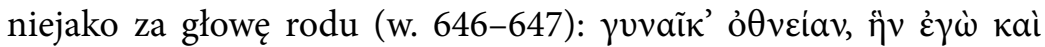

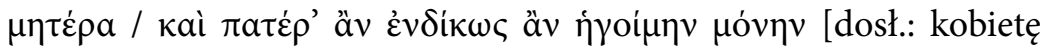
obcą, którą jako jedyną, mógłbym słusznie uznać za matkę i ojca]. Żeby jednak dopełnić horroru zniszczenia filia w rodzinie, Admet rzuca najstraszniejsze przyrzeczenie, godzące w boski porządek oikos (w. 665-666):

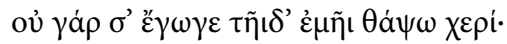

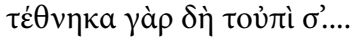

[bo ja tą ręką grzebać cię nie będę

/ Dla ciebie zmarłem.]

Po tych słowach definitywnie przyjmuje Alkestis jako substytut rodziców, ale czyni to w bardzo zaskakujący i enigmatyczny sposób mówiąc (w. 666-668):

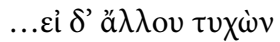

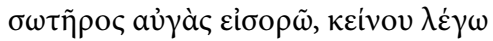

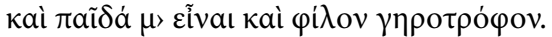

\section{[...Inny zbawca dał mi oglądać}

Światło, jego się mienię

Synem, kochanym starca żywicielem.]

Król nie wspomina tutaj o czci należnej zmarłemu rodzicowi, co byłoby bardziej logiczne w kontekście sytuacji w sztuce, nie mówi, że swemu zbawcy wyprawi godny pogrzeb. Zobowiązuje się jednak, choć Alkestis nie żyje, że będzie jej „żywicielem w starości”. Mamy tutaj do czynienia albo z kolejnym przejawem egzaltowanej wypo- 
wiedzi, albo z pewnego rodzaju przepowiednią. Widz wie, że żona powróci do domu i może rozumieć również, że oto Admet zapowiada, jaka będzie sytuacja po jej zmartwychwstaniu. Rodzice pozostaną wykluczeni z oikos, a należne im miejsce zajmie żona. Tu powracamy do dziwnej zamiany ról, z jaką mamy do czynienia w dramacie. Lusching zwraca uwagę na szczególną i pozornie niezrozumiałą zamianę zaimków w wersach 667-668 ${ }^{45}$ : keivov jest formą męską, gramatycznie dostosowaną do $\sigma \omega \tau \eta \dot{\rho}$ (gr. zbawca), ale logicznie nieuprawnioną ze względu na osobę, o której mowa. Oto dopełnia się inwersja miejsc i pozycji w rodzinie Admeta: żona zostaje wywyższona ponad męża.

Wiele już powiedziano na temat postaci Admeta w sztuce Eurypidesa, To on jest przecież głównym bohaterem i jego dotyczy wszystko, co się w sztuce wydarzy. Spodziewamy się zatem, że to właśnie jego cierpienie uczyni mądrzejszym ${ }^{46}$, staje się jednak inaczej. U Eurypidesa nic nie może być ani banalne, ani proste. Nie zapominajmy, że oboje bohaterowie znani byli Ateńczykom głównie z folkloru i że postacie sztuki wystawionej w miejsce dramatu satyrowego nie moga być monotonnie patetyczne, przynajmniej nie wszystkie. Na tle pozornie posągowej żony charakter Admeta jest niejednoznaczny ${ }^{47}$.

Współcześni interpretatorzy uznają za pewnik, że ateński widz doskonale wiedział, dlaczego życie Admeta jest tak ważne dla królestwa Feraj, że ktoś musi za niego poświęcić swoje. Tymczasem

45 C.A.E. Lusching, Imaginary Spaces..., s. 25.

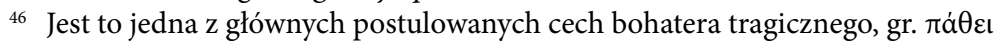

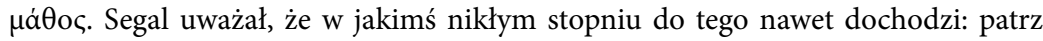
C. Segal, Euripides' Alcestis: Female Death and Male Tears, „Classical Antiquity” 11 (1992), no. 1, s. 142-158, (szczególnie s. 147).

47 Ocena postaci jest tematem rozlicznych prac szczegółowych (polecić można ciekawą analizę między innymi subiektywnego zaangażowania uczonych w interpretację zachowań i charakteru postaci w E.E. Bradley, Admetus and the triumph of failure in Euripides' Alcestis, „Ramus” 9 (1980), s. 112-127), jednak niemalże każde opracowanie tragedii w jakiś sposób podejmuje próbę oceny wad i zalet głównego bohatera. 
Eurypides nie mówi tego nigdzie wprost, nie pokazuje żadnej cechy władcy, która czyniłaby go monarchą niezastąpionym, najlepszą opcją dla lokalnej społeczności. Jedyną jego niezaprzeczalną cnotą jest bezwzględna wierność zasadom xenia, za co chwali go nawet chór (w. 595-505). W exodosie okaże się jednak, że nawet tę świętość Admet potrafi niechcący zszargać. Herakles wypomina mu to w wersach 1008-1018, zaznaczając na początku, że podstawą filia jest prawdomówność, której król nie uszanował, nie mówiąc gościowi wprost o powodach żałoby w pałacu. Wzgląd na złą sławę i zarzut niegościnności sprawiają, że Admet stawia Heraklesa w trudnej sytuacji - swoją nocną hulanką to on łamie zasady uszanowania świętości gościnnego domu, on łamie nieświadomie xenia. Dlatego Herakles mówi (w. 1017):

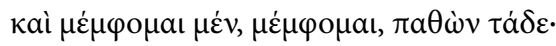

[I za złe mam ci, za złe, coś uczynił.]

Jednocześnie wiemy, że znaczącym elementem manipulacji króla, noszącej znamiona kłamstwa, było przedstawienie Alkestis jako „obcej” (w. 533) ${ }^{48}$. Ma to miejsce już po przyrzeczeniu jej nawet pośmiertnej wierności i czci.

Eurypides, pokazując całą niedoskonałość króla, chce, by widz miał od początku do końca sztuki poczucie dysproporcji między ofiarą i jej skutkiem. W micie, a co za tym idzie także i w tragedii greckiej, poświęcenie za społeczność jest zjawiskiem obecnym, a co najważniejsze, $\mathrm{w}$ dramacie zawsze uzasadnionym ${ }^{49}$. Śmierć za

48 Oczywiście Alkestis jest „obca”, w takim sensie, jak każda kobieta grecka wchodząca do domu męża, nie należy do jego prymarnego oikos. Król mówi poniekąd prawdę, co zauważa większość badaczy. Jednak sytuacja zmienia się wraz z przyjęciem jej jako „ojca i matki”, nie tylko żony. Admet neguje zatem nie tylko związek filia z żoną, ale także narzucony przez niego samego nowy status zmarłej.

49 Polemika $\mathrm{z}$ takim uzasadnieniem w przypadku śmierci Polikseny jest jednym z głównych motywów mających usprawiedliwić zbrodnię Klitajmestry w Agamemnonie Ajschylosa (w. 1412). 
jednostkę jest aktem wyjątkowym ${ }^{50}$. Można się zatem spodziewać, że Eurypides przedstawi publiczności szersze powody, dla których życie Admeta jest tak ważne. Argument opieki nad dziećmi, który zdaje się być kluczowy dla Alkestis, jest z punktu widzenia społeczności nieistotny. Dramaturg unika rozwinięcia tego wątku, ukazuje tylko prywatną motywację żony i matki. W zamian za to mamy przedstawienie męża, którego pod niemal każdym względem przewyższa umierająca kobieta. Komizm i tragizm postaci Admeta łączą się w jedną całość. Główny bohater tragedii greckiej musi w sztuce doświadczyć cierpienia i straty, czasem także wielkiego upokorzenia i... przeżyć, pokazując, że ból go uszlachetnił.

Tymczasem pomimo wszelkich oznak udręki Admet nie tylko pozostaje sobą, ale na końcu dopełnia się jego smutny obraz egotyka i kłamcy. Eurypides konstruuje swoją fabułę w ten sposób, by pokazać, że Admet nie jest w stanie przejść przemiany tragicznej i jedyną osobą, która zdaje się o tym wiedzieć od początku, jest właśnie Alkestis. Zarówno ona, jak i chór przygotowują nas na ostateczną zdradę. Król łamie wszystkie swoje solenne obietnice. Zarzeka się, że pałac będzie od śmierci władczyni miejscem wiecznej żałoby, że nie będzie żadnych śpiewów i hulanek. Tymczasem jeszcze przed właściwą ceremonią pogrzebową część domu Admeta będzie świadkiem pijackiej zabawy. Najbardziej dramatyczną scenę przygotowuje jednak dla nas Eurypides na koniec sztuki - oto mąż w żałobie, który uroczyście zaklinał się, że nie przyjmie do domu innej kobiety, namawiany przez przyjaciela, bierze za żonę nieznajomą dziewczynę. Tragediopisarz mógł nam tej sceny oszczędzić, Alkestis mogła zostać wprowadzona przez Heraklesa bez woalu. Ale Admet musi dokonać tragicznego wyboru i musi nastąpić tragiczne rozpoznanie (anagnorismos). Wszystko to staje się po scenie, w której możemy oczekiwać, że król nareszcie zrozumiał, kim sam jest i co się stało. Ostatnia długa rozmowa $\mathrm{z}$ chórem kończy się samokrytyczną wypowiedzią

50 Dla porównania wystarczy przeanalizować motywację Makairy w Dzieciach Heraklesa. 
Admeta, w której wyraża on także strach przed samotnością i hańbą (w. 935-961). Swoim najbliższym skarży się najpierw na opuszczenie i pustkę w domu, a zatem albo ignoruje ich obecność, albo spodziewa się po nich, że opłakując panią, podobnie jak dzieci, nie będą zwracali na niego uwagi. Nikt nie odpowie na jego pozdrowienie, ale i on nikogo nie pozdrowi. Poza pałacem natomiast będzie się obawiał widoku kobiet (!) i nieprzyjaznych mu obywateli, którzy zarzucą mu tchórzostwo, lżenie rodziców i skazanie żony na śmierć. W tej wypowiedzi dystansuje się jednak od własnej winy, bowiem tego, kto

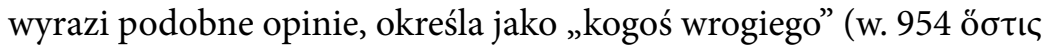
$\varepsilon \chi \chi \theta \rho o ̀)$. Ale wypowiedź ta zaczyna się i kończy swoistą negacją poświęcenia Alkestis (w. 935n.):

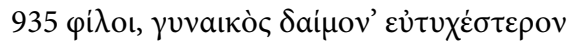

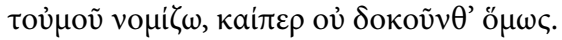

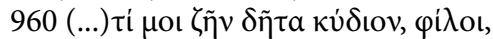

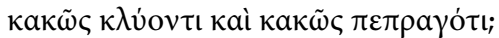

[935 Drodzy, ja myślę, że los mojej żony

Jest - wbrew pozorom - od mego szczęśliwszy.

960 (...) Po cóż mi żyć, przyjaciele,

Osławionemu i nieszczęśliwemu.]

Po raz kolejny egotycznie stawia Admet swoje cierpienie ponad los innych, lecz ukazuje również, że czyn Alkestis nie był warty życia, które teraz może wieść. W tragedii żadna ofiara nie może być bezowocna, ponieważ naruszałaby nie tylko logiczny, ale i boski porządek świata. Tymczasem tutaj dojmujące poczucie bezsensu towarzyszy widzowi od początku sztuki. Eurypides celowo pokazuje niedorzeczność śmierci osoby pełnej arete i eukleia w miejsce kogoś, kto sam o sobie mówi, że świat widzi go jako wiodącego podłe i nikczem-

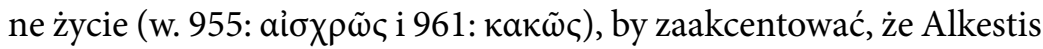
musi wrócić. Segal zwraca uwagę na swego rodzaju niestosowność płaczu Admeta. Choć bohaterowie eposu i tragedii płaczą dosyć często, dzieje się to zawsze w momentach szczególnie dramatycznych lub, znacznie częściej, w przypadku ogromnego upokorzenia. Admet 
lamentuje koncentrując się na sobie i swoim bólu, nigdzie jednak nie bierze odpowiedzialności za zaistniałą sytuację, która jest konsekwencją wyłącznie jego prośby i postawy wobec śmierci. Zawodzenie króla jest nie tylko nieadekwatne i nieodpowiednie wobec jego pozycji, co zauważył Segal, ale chyba przede wszystkim przekracza granice absurdu i scenicznego poczucia tragizmu. Niedorzeczność tego zewnętrznego wyrazu rozpaczy podkreślą słowa o pragnieniu śmierci (w. 273-279, 382). Mąż podważa tym samym, jak już pokazaliśmy wyżej, sens ofiary żony. Szloch Admeta jest tym bardziej szokujący, gdy uświadomimy sobie, że jedyna scena rozpaczy Alkestis ma miejsce poza sceną, znamy ją tylko z relacji służebnej.

W wersji Eurypidesa Alkestis umiera nie za męża, a w miejsce męża, nie nienawidząc „łoża ślubnego” ${ }^{51}$. Gdy poznajemy Alkestis, jest ona już na granicy pomiędzy życiem na ziemi a rzeczywistością hadesową. Jako jedyna ma kontakt $\mathrm{z}$ chtonicznymi bóstwami, widzi je i do nich mówi. Na przestrzeni sztuki ta prywatna heroizacja zamieniać się będzie powoli w regularny kult. Ostatecznie dokona się ona w swoistym manifeście chóru (997n.):

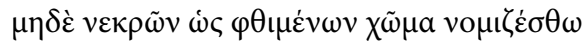

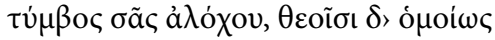

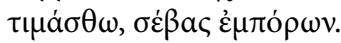

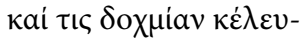

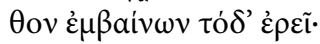

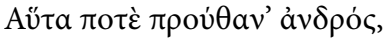

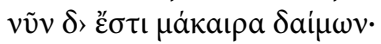

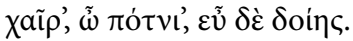

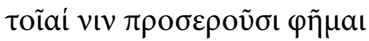

[I niech nikt nie uważa, że to kopiec nad zmarłą, Grób twej żony niech cześć bierze bogom podobną, Miejsce czci pobożnej przechodniów.

${ }^{51}$ Szczególnie użytkownik języka polskiego musi w tym wypadku zachować czujność. Tym bardziej, że w kręgu kultury chrześcijańskiej, gdzie Chrystus ponosi śmierć „za” człowieka, można z łatwością zboczyć na interpretacyjne manowce. 
A ktoś, spadzistą ścieżką

Schodzący, powie:

„Ona kiedyś umarła za męża,

Teraz jest bóstwem szczęśliwym.

Witaj, Pani, i bądź nam przychylna!”

Tak będą się do niej zwracać.]

Użyte $\mathrm{w}$ istotnej kolejności tytuły: bogom równa ( $\theta \varepsilon$ coĩ $\delta^{\prime}$

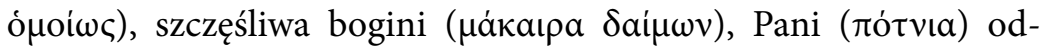
zwierciedlają proces heroizacji. Szczególnie ostatni „oficjalny” zwrot, jakim od tej pory należy zwracać się do królowej, określa jej status bóstwa. W greckiej religijności nie ma przykładów odwrócenia takiej apoteozy $^{52}$. Na końcu sztuki zatem spotka się odarty nawet ze swej największej cnoty - gościnności - Admet, co dobitnie uświadamia nam wypowiedź Heraklesa, i Alkestis, milczące bóstwo powracające ze świata nieżywych ${ }^{53}$. Ewolucja percepcji głównej bohaterki sztuki 745/6:

52 Jakie miejsce ma zająć Alkestis po śmierci, przewiduje chór już w wersach

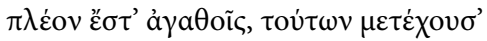

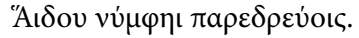

[A jeśli tam dobrym większe przyznano zaszczyty,

Mniej i ty w nich część swoją - zasiądź przy żonie Hadesa.]

53 O dziwnym statusie martwej - żywej bohaterki patrz: G.G. Betts, The Silence of Alcestis, „Mnemosyne” 18 (1965), s. 181-182. Bez wątpienia kobieta jest w pewnym sensie deuteropotmos (żywym, który został uznany za martwego oraz pochowany i musi się oczyścić z miasmy śmierci). Herakles uzasadnia jej milczenie

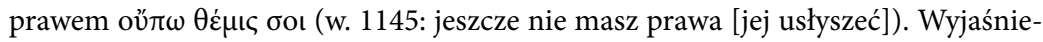
nie dotyczące czasu ( 3 dni), który powinien upłynąć, by „martwy” mógł na powrót zaistnieć w świecie żywych, patrz: E.P. Trammell, The Mute Alcestis, w: Twentieth Century Interpretations of Euripides' Alcestis: A Collection of Critical Essays, ed. by J.R. Wilson, New York 1968, s. 85-91. Tym bardziej dziwne jest zakończenie sztuki, w którym Admet nie tylko wprowadza żonę za rękę do pałacu, ale i zapowiada, że całe miasto ma składać ofiary dziękczynne z wołów, a nie odprawiać rytuały oczyszczające (w. 1153-1159). Ciekawą interpretację milczenia Alkestis oraz jej istnieniem pomiędzy „życiem a śmiercią”, znajdziemy w R. Buxton, Euripides' Alcestis: Five Aspects of Interpretation, w: idem, Myths and Tragedies in Their Ancient Greek Context, Oxford 2013, s. 201-218 (= Papers given at s Colloquium on Greek Drama in honour of R. P. Winnington-Ingram, ed. by L. Rodley, London 1987, s. 17-31), 
Eurypidesa przebiega od ubóstwienia filia Alkestis w wersach 279n. do ubóstwienia jej samej. Słowa modlitwy skierowanej do Alkestis wyznaczają jej ostateczną pozycję w oikosie, a może już poza nim, czy nawet ponad nim. Jako postać w sztuce żona Admeta pozostaje statyczna, nie przechodzi żadnej przemiany, nie jest targana wątpliwościami, ale tym bardziej zauważalna jest zmiana, jaka dokonuje się w innych bohaterach i ich percepcji władczyni. Aristeia kobiety prowadzi do heroizacji, której podstawą zaś jest paradoksalnie jej męstwo (arete) w każdym wymiarze tego słowa, zarówno odwagi, jak i cnoty typowej dla głowy rodziny ${ }^{54}$. Ta heroizacja jest zresztą w pewnym sensie zapowiedziana przez chór już na samym początku dramatu (w. 445-454, zacytowane we wstępie do tego artykułu) ${ }^{55}$. Eurypides nie wygrał konkursu, na którym zaprezentował sztukę. Sędziowie przyznali pierwszą nagrodę Sofoklesowi i jego zaginionej i nieznanej nam nawet $\mathrm{z}$ tytułu tetralogii. Można się spodziewać, że

gdzie autor zwraca uwagę nie tylko na obrzędowe zasłanianie kobiety, ale i milczenie $\mathrm{w}$ trakcie uroczystości ślubnych (rytuał przejścia). Fascynacja „milczeniem Alkestis" w literaturze naukowej jest wyraźnie widoczna, szczególnie frapująca jest dramaturgiczna rola takiej niemej postaci. Próbowano wyjaśniać ją niechęcią Eurypidesa do scen $\mathrm{z}$ trzema mówiącymi aktorami lub parodią milczących postaci u Ajschylosa (patrz: A.W. Verrall, Euripides the Rationalist, Cambridge 1895, s. 69-70) lub wyczuciem patosu - milcząca Alkestis jest znacznie bardziej wymowna i „koturnowa" (np. G.M.A. Grube, The Drama of Euripides, London 1941, s. 145). Do pomysłów niektórych badaczy, w różny sposób wyjaśniających, że bohaterka sztuki umiera definitywnie (D.L. Drew, Euripides' Alcestis, „The American Journal of Philology" 52 (1931), no. 4: 295-319) lub, że Herakles przyprowadza inną osobę (tak J. Kott w eseju pt. Welon Alcesty, w słynnym dziele Zjadanie bogów i nowe eseje, Kraków 1999) nie będziemy się tutaj odnosić.

${ }^{54}$ Tutaj należy zauważyć, że podobną próbę podejmie Eurypides w przedstawieniu Makarii w Dzieciach Heraklesa, w tej sztuce punktem wyjścia jest jednak ateńska legenda eponimiczna o heroinie źródła, którą stałą się bohaterka po tym, gdy została ofiarowana bogom. Motywacja dziewczyny w sztuce także bazuje na dobrej sławie (kleos) i poświęceniu za braci.

${ }_{55}$ O religijnym i heroicznym pośmiertnym statusie Alkestis patrz C. Sourvinou-Inwood, Reading Greek Death: To the End of the Classical Period, Oxford - New York 1995, s. 187, oraz A. Markantonatos, Euripides' Alcestis: Narrative, Myth, and Religion, Berlin - Boston 2013, s. 150, z dalszą bibliografią. 
nie tylko rewolucyjny pomysł pokazania czwartej, choć weselszej, tragedii na zakończenie widowiska, ale i sama interpretacja postaci najlepszej z kobiet i tchórzliwego męża nie przypadły Ateńczykom do gustu. Dopiero kolejne pokolenia Hellenów przekonały się do Alkestis, tak jak zresztą do wielu innych sztuk poety. Dramat pozostaje także punktem wyjścia zarówno w nowożytnych, jak i szczególnie w nam współczesnych interpretacjach „powrotu Alkestis”.

\section{Bibliografia}

Bassi K., The Actor as Actress in Euripides' Alcestis, „Themes in Drama” 11 (1989), s. 19-30.

Belfiore E.S., Murder among Friends: Violation of Philia in Greek Tragedy, Oxford 2000.

Berg B., Alcestis and Hercules in the Catacomb of Via Latina, „Vigiliae Christianae” 49 (1994), s. 219-234.

Betts G.G., The Silence of Alcestis, „Mnemosyne” 18 (1965), s. 181-182.

Binney E.H., The Alcestis as a Folk-Drama, „Classical Review” 19 (1905), no. 2, s. 98 99.

Boccaccio G., Genealogiae Deorum Gentilium Libri, ed. V. Romano, Bari 1951.

Bradley E.E., Admetus and the triumph of failure in Euripides' Alcestis, „Ramus” 9 (1980), s. 112-127.

Burnett A., The Virtues of Admetus, „Classical Philology” 60 (1965), no. 4, s. 240-255.

Butler E.M., Alcestis in Modern Dress, „Journal of the Warburg Institute” 1 (1937), s. $46-60$.

Buxton R., Euripides' Alcestis: Five Aspects of Interpretation, w: idem, Myths and Tragedies in Their Ancient Greek Context, Oxford 2013, s. 201-218 (= Papers given at a Colloquium on Greek Drama in honour of R. P. Winnington-Ingram, ed. by L. Rodley, London 1987, s. 17-31).

Conacher D., Euripides and the Sophists, London 1998.

Cooper J.M., Aristotle on the forms of friendship, „Review of Metaphysics” 30 (1977), s. 619-648.

Cooper J.M., Friendship and the Good in Aristotle, „Philosophical Review” 86 (1977), s. 290-315,

Cooper J.M., Aristotle on friendship, w: Essays on Aristotle's Ethics, ed. by A.O. Rorty, Berkeley 1980, s. 301-340.

Czerwińska J., Agony racji w "Alkestis" Eurypidesa, „Collectanea Philologica” 1 (1995), s. 91-102. 
Czerwińska J., Euripides i jego twórczość, w: Literatura Grecji starożytnej. Epika Liryka - Dramat, red. H. Podbielski, Lublin 2005, s. 830-834.

Dellner J.J., Alcestis' Double Life, „The Classical Journal” 96 (2000), no. 1, s. 1-25.

Drew D.L., Euripides' Alcestis, „The American Journal of Philology” 52 (1931), s. $295-319$.

Dyson M., Alcestis' Children and the Character of Admetus, „Journal of Hellenic Studies" 108 (1988), s. 13-23.

Euripides, Alcestis, ed. by L.P.E. Parker, Oxford 2007.

Foley H.P., Anodos Dramas: Euripides' Alcestis and Helen, w: Innovations of Antiquity, eds. by R. Hexeter, D. Selden, New York 1992, s. 133-134.

Fritz K. von, Euripides' Alestis und ihre modernen Nachahmer und Kritiker, „Antike und Abendland" 1956, s. 27-70.

Grube G.M.A., The Drama of Euripides, London 194.

Herman G., Ritualised Friendship and the Greek City, Cambridge 1987.

Konstan D., Friendship in the Classical World, Cambridge 1997.

Kott J., Zjadanie bogów i nowe eseje, Kraków 1999.

Lesky A., Alkestis, der Mythus und das Drama, Wien - Leipzig 1925.

Lusching C.A.E., Imaginary Spaces in Alcestis and Medea, „Mnemosyne” 45 (1992), no. 1, s. 19-44.

Luschnig C.A.E., Euripides' Alcestis and the Athenian Oikos, „Dioniso” 60 (1990), s. 9-39.

Łanowski J., Eurypides Tragedie: Alkestis, Warszawa 1967.

Markantonatos A., Euripides' Alcestis: Narrative, Myth, and Religion, Berlin - Boston 2013.

Miles S., Greek Drama in the Hellenistic World, w: A Handbook to the Reception of Greek Drama, ed. B. van Zyl Smit, Chichester, West Sussex 2016. s. 45-62.

Nervegna S., Performing Classics. The Tragic Canon in the Fourth Century and Beyond, w: Greek Theatre in the Fourth Century BC, ed. by E. Csapo, H.R. Goette, J.R. Green, P. Wilson, Göttingen 2014, s. 157-188.

Nervegna S., Staging Scenes or Plays? Theatrical Revivals of 'Old' Greek Drama in Antiquity, „Zeitschrift für Papyrologie und Epigraphik” 162, s. 14-42.

O'Bryhim S., The Economics of Alagmatophilia, „The Classical Journal” 110 (2015), no. 4, s. 419-429.

Parker L.P.E., Alcestis: Euripides to Ted Hughes, „Greece \& Rome” 50, (2003), no. 1, s. $1-30$.

Pertusi A., Il ritorno alle fonti del teatro greco classico: Euripide nell'Umanesimo e nel Rinascimento, w: idem, Venezia e L'Oriente fra Tardo Medioevo e Rinascimento, Firenze 1966, s. 205-224.

Pertusi A., La scoperta di Euripide nel primo Umanesimo, „Italia Medioevale e Umanistica" 3 (1960), s. 101-152.

Price A.W., Love and Friendship in Plato and Aristotle, Oxford 1989. 
Rabinowitz N., Anxiety Veiled: Euripides and the Traffic in Women, Ithaka - London 1990.

Revermann M., The Reception of Greek Tragedy from 500-323 BC, w: A Handbook to the Reception of Greek Drama, ed. by B. van Zyl Smit, Chichester 2016, s. 11-28.

Rogers K., Aristotle on loving another for his own sake, „Phronesis” 39 (1994), s. 291-302.

Roisman H.M., Alcestis, w: Brill's Companion to the Reception of Euripides, ed. by R. Lauriola, K.N. Demetriou, Leiden - Boston 2015, s. 349-376.

Schein S.L., ФINIA in Euripides' Alcestis, „Mètis. Anthropologie des mondes grecs anciens" 3 (1988), no. 1-2, s. 179-206.

Schollmeier P., Other Selves. Aristotle on Personal and Political Friendship, New York 1994.

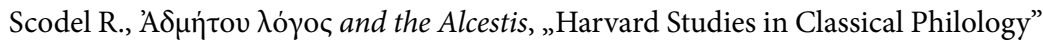
83 (1980), s. 51-62.

Segal C., Euripides' Alcestis: Female Death and Male Tears, „Classical Antiquity” 11 (1992), no. 1, s. 142-158.

Segal C., Euripides and the Poetics of Sorrow, Durham - London 1993.

Sicking C.M.J., Tragédie d’amour ou tragédie du devoir?, „Mnemosyne” 41 (1967), s. $155-174$.

Slater N.W., Euripides: Alcestis, London 2013.

Smith W.D., The Ironic Structure in Alcestis, „Phoenix” 14 (1960), s. 127-145.

Sourvinou-Inwood C., Reading Greek Death: To the End of the Classical Period, Oxford - New York 1995.

Stanton G.R., Philia and Xenia in Euripides 'Alcestis', „Hermes” 118 (1990), s. 42-54.

Steffen W., Baśn ludowa w greckim dramacie satyrowym, „Meander” 8 (1953),

s. 216-223 (= Scripta minora selecta I, Wrocław 1973, s. 320-326).

Stern-Gillet S., Aristotle's Philosophy of Friendship, Albany 1995.

Thury E.M., Euripides' Alcestis and the Athenian Generation Gap, „Arethusa” 21 (1988), s. 199-206.

Trammell E.P., The Mute Alcestis, w: Twentieth Century Interpretations of Euripides' Alcestis: A Collection of Critical Essays, ed. by J.R. Wilson, New York 1968, s. 85-91.

Vernant J.-P., Du double à l'image - Figuration de l'invisible et catégorie psychologique du double:le colossus, w: idem: Mythe et pensée chez les Grecs, Paris 1985, s. 325-328.

Verrall A.W., Euripides the Rationalist, Cambridge 1895.

Whiting J., The Nicomachean Account of Philia, w: Blackwell Guide to Aristotle's Nicomachean Ethics, ed. by R. Kraut, Cambridge 2006, s. 276-304.

Wilamowitz-Moellendorff U. von, Griechische Tragödien, t. 3, Berlin 1906. 